\title{
cDNA-SSR MARKERS FOR MOLECULAR EPIDEMIOLOGY OF Ganoderma boninense
}

TUNG HUN JIAT*; SITA ASTARI ${ }^{\star *}$; GOH YOU KENG‡; GOH KAH JOO‡ and WONG WEI CHEE*

\begin{abstract}
Basal stem rot (BSR) caused by G. boninense is the most devastating and yield-limiting disease for the oil palm industry in South-east Asia. Information on the population biology of G. boninense for testing important hypotheses concerning BSR infection is lacking. This article describes the development of the most discerning molecular marker to date, i.e. $c D N A-S S R$, in an attempt to evaluate the genetic diversity and epidemiology of G. boninense. The Belitung Island in Indonesia was chosen for this study because it has BSR disease spread in first generation plantings of oil palm, and geographically not connected to the Sumatra main island. There are considerable field experiences alongside the indepth genetic analyses presented here. The basidiocarps of G. boninense collected from BSR and upper stem rot (USR) infected oil palm were confirmed as G. boninense by phylogenetic analysis. The marker data inferred that the G. boninense isolates were very diverse, with heterozygosity of 0.777 , reflecting random mating and the outcrossing nature of this fungus. Clonal spread was not found in the present study and isolates were genetically different, from palm to palm. The hierarchical cluster analysis and distance-standardised principal coordinates analysis suggested G. boninense spread from the coastal region (north) to inland areas (south) on Belitung Island. Despite the very small sample size, the thorough analyses revealed major shortcomings and difficuties in developing a set of polymorphic cDNA-SSR markers for epidemiology of G. boninense.
\end{abstract}

Keywords: Ganoderma boninense, Elaeis guineensis Jacq., cDNA-SSR, genetic diversity, epidemiology.

Date received: 25 May 2018; Sent for revision: 18 August 2018; Received in final form: 25 November 2018; Accepted: 25 March 2019.

\section{INTRODUCTION}

Oil palm (Elaeis guineensis Jacq.) is a perennial oil crop that produces the highest oil yield per hectare in the world. Currently, Indonesia and Malaysia are

* Biotechnology Section,

Advanced Agriecological Research Sdn Bhd,

AAR-UNMC Biotechnology Research Centre,

Jalan Broga, 43500 Semenyih, Selangor, Malaysia.

E-mail:wongwc@aarsb.com.my

** PT Applied Agricultural Resources Indonesia (PT AARI, Subsidiary company of Applied Agricultural Resources Sdn Bhd), Kompleks Taman Anggrek Block D1. JI Tuanku Tambusai, Pekanbaru, 28291 Riau, Indonesia.

₹ Advanced Agriecological Research Sdn Bhd, Jalan Teknologi 3/6, Taman Sains Selangor 1 , Kota Damansara, 47810 Petaling Jaya, Selangor, Malaysia. the first and second largest palm oil exporters in the world but both are facing severe losses from the incidence of basal stem rot (BSR) infection in their oil palm plantations. BSR is the most devastating, yieldlimiting disease of the oil palm in both countries (Chung, 2011). It was first reported in Malaya (now Malaysia) by Thompson in 1931 and the causal agent was then identified as Ganoderma lucidum. In 1967, Steyaert reported another six Ganoderma species associated with BSR in the oil palm (i.e. G. boninense Pat, G. miniatocinctum Steyaert, G. chalceum [Cooke] Steyaert, G. tornatum [Pers.] Bers, G. zonatum Murill and G. xylonoides Steyaert).

Although many more Ganoderma species had been associated with BSR, a number of studies in Indonesia and Malaysia indicated that the main 
causal pathogen of BSR is the single species of Ganoderma boninense (Idris and Ariffin, 2004). BSR was mainly confined to palms more than 25 years old until the mid-1950s when it started infecting 10- to 15-year old palms (Turner, 1981). Infection on palms as early as one to two years after planting have been reported by Singh (1991). Once considered a problem only in the coastal-marine-clay areas of western Peninsular Malaysia (Navaratnam, 1964), the disease has been frequently found in coastal (Khairudin, 1990), peat (Lim and Udin, 2010) and inland areas (Chung, 2011). Furthermore, the G. boninense is also the purported causal agent of upper stem rot (USR) in oil palm, which is neither related to BSR nor show rotting symptoms on trunk base or root (Flood et al., 2002). Currently, there is no effective treatment for BSR and USR due to limited knowledge of $G$. boninense invasion strategies and the absence of known resistance to the disease in oil palm.

G. boninense, a basidiomycete, has heterothallic and tetrapolar mating system with multiple alleles at both mating type loci, which favours outcrossing (Pilotti et al., 2002; 2003; Pilotti, 2005). The basidiocarp morphology of G. boninense varies among the BSR diseased palms. The use of macromorphology to distinguish among isolates is unreliable and subjective because the morphology can vary substantially with the availability and quality of food sources and environmental conditions (Cannon and Sutton, 2011). Currently, Ganoderma selective medium (GSM) (Ariffin and Idris, 1991) was used to obtain pure culture of $G$. boninense and its identity was confirmed using internal transcribed spacer (ITS) region and $18 \mathrm{~S}$ fungal ribosomal gene. In order to accomplish the development of an effective control measure for BSR disease infection in oil palm, a precise molecular diagnostic method that enables the measurement of pathogen genetic diversity and spreads of the pathogen may be necessary.

Within a field, root-to-root contact was thought to be the main disease spread mechanism, primarily based on anecdotal evidence that BSR occurs loosely in patches of palms (Singh, 1991). Moreover, stumps and roots are thought to host the primary inoculum for the disease. Palms planted near or over excavated diseased stumps had low disease incidence, but palms planted near or over unexcavated stumps had high disease incidence (Khairudin, 1990; Ariffin and Idris, 2002). In 1999, Miller et al. used a combination of mtDNA variability and somatic incompatibility to arrive at the postulation that BSR does not spread by direct root-to-root contact between palms. Research carried out by Cooper et al. (2011) provided further information on BSR spread through basidiospore dispersal and mode of root infection as well as lower stem invasion by G. boninense.
With the advent of using genetic marker as a tool in recent years, it is now possible to apply it to population genetics to deduce the spread of pathogen populations and mode of reproduction in many fungi e.g. Heterobasidion annosum s.s. and H. parviporum (Oliva et al., 2011), grape vine powdery mildew, Erysiphe necator (Brewer and Milgroom, 2010; Frenkel et al., 2012) and Holocryphia eucalypti that causes stem cankers on Eucalyptus species in South Africa and Australia (Nakabonge et al., 2008). The aim of this study was to investigate the genetic relationship among isolates collected from both coastal and inland areas of Gunung Nayo, Belitung Island $\left(2^{\circ} 50^{\prime} \mathrm{S} 107^{\circ} 55^{\prime} \mathrm{E}\right)$, off the east coast of Sumatra, Indonesia where the oil palms are still at the first generation of planting. We also describe the development of genotyping using CDNA-SSR marker and provide an assessment of the advantages and shortfalls of using marker-inferred genetic diversity and molecular epidemiology of $G$. boninense.

\section{MATERIALS AND METHODS}

\section{Ganoderma boninense Isolates and Growth Conditions}

There are two isolates of $G$. boninense originating from basidiocarps collected by Advanced Agriecological Research Sdn Bhd (AAR) at Paloh Substation, Johor, Malaysia and Felda Global Ventures Research and Development Sdn Bhd (FGV R\&D) at Serting Hilir Research Station, Negeri Sembilan, Malaysia, sent for transcriptome sequencing (unpublished data). A total of 17 isolates from basidiocarps collected from Gunung Nayo $(\mathrm{GN})$, Belitung Island $\left(2^{\circ} 50^{\prime} \mathrm{S} 107^{\circ} 55 \mathrm{E}\right)$, Indonesia (Table 1 and Figure 1) were cultured by the method described by Ariffin and Idris (1991). After isolation of G. boninense mycelia, pure cultures were maintained on solid malt extract agar (MEA). The culture plates were kept at $26 \pm 2^{\circ} \mathrm{C}$ in the dark condition. Another set of 15 isolates of G. boninense (12 from BSR and 3 from USR), fungal and bacterial species (Table 2) that were used for marker polymorphism and specificity testing were obtained from fruiting bodies sampled from Ganoderma diseased oil palm in estates located in Peninsular Malaysia. The other fungi and bacteria species were included in the testing to remove the cDNA-SSR markers not specific to G. boninense.

\section{Sampling of G. boninense Basidiocarps at Gunung Nayo}

Sampling of basidiocarps was conducted when the size of basidiocarps growing on standing, infected palms in the field reached $50 \mathrm{~mm}$ in length/width of bracket-shaped form. This required monitoring the increasing size of basidiocarps every two weeks 
TABLE 1. Ganoderma boninense ISOLATES COLLECTED FROM GUNUNG NAYO (GN), BELITUNG ISLAND, INDONESIA

\begin{tabular}{|c|c|c|c|c|c|}
\hline No. & Sample code & GenBank accession number & Block & Type & Disease incidence \\
\hline 1 & $\mathrm{~B} / 1 / 001$ & KY471673 & GN01 & BSR & Low \\
\hline 2 & $\mathrm{~B} / 1 / 002$ & KY471674 & GN01 & BSR & Low \\
\hline 3 & $\mathrm{~B} / 1 / 003$ & KY471675 & GN01 & BSR & Low \\
\hline 4 & $\mathrm{U} / 3 / 005$ & KY471689 & GN03 & USR & Severe \\
\hline 5 & $\mathrm{~B} / 4 / 008$ & KY471676 & GN04 & BSR & Very low \\
\hline 6 & $\mathrm{~B} / 4 / 009$ & KY471677 & GN04 & BSR & Very low \\
\hline 7 & $\mathrm{~B} / 4 / 013$ & KY471678 & GN04 & BSR & Very low \\
\hline 8 & $\mathrm{~B} / 4 / 014$ & KY471679 & GN04 & BSR & Low \\
\hline 9 & B/5/011 & KY471680 & GN05 & BSR & Low \\
\hline 10 & B/5/029 & KY471681 & GN05 & BSR & Moderate \\
\hline 11 & B / 6/017 & KY471682 & GN06 & BSR & Severe \\
\hline 12 & B/6/019 & KY471683 & GN06 & BSR & Severe \\
\hline 13 & B/6/024 & KY471684 & GN06 & BSR & Severe \\
\hline 14 & $\mathrm{~B} / 6 / 027$ & KY471685 & GN06 & BSR & Severe \\
\hline 15 & B/6/039 & KY471686 & GN06 & BSR & Moderate \\
\hline 16 & $\mathrm{~B} / 7 / 035$ & KY471687 & GN07 & BSR & Severe \\
\hline 17 & $\mathrm{~B} / 7 / 037$ & KY471688 & GN07 & BSR & Severe \\
\hline
\end{tabular}

Note: B - basal stem rot. U - upper stem rot. First coding digit (1-7) refers to the block number. The last three digits in the sample code refer to the palm sequence number given during the palm marking.

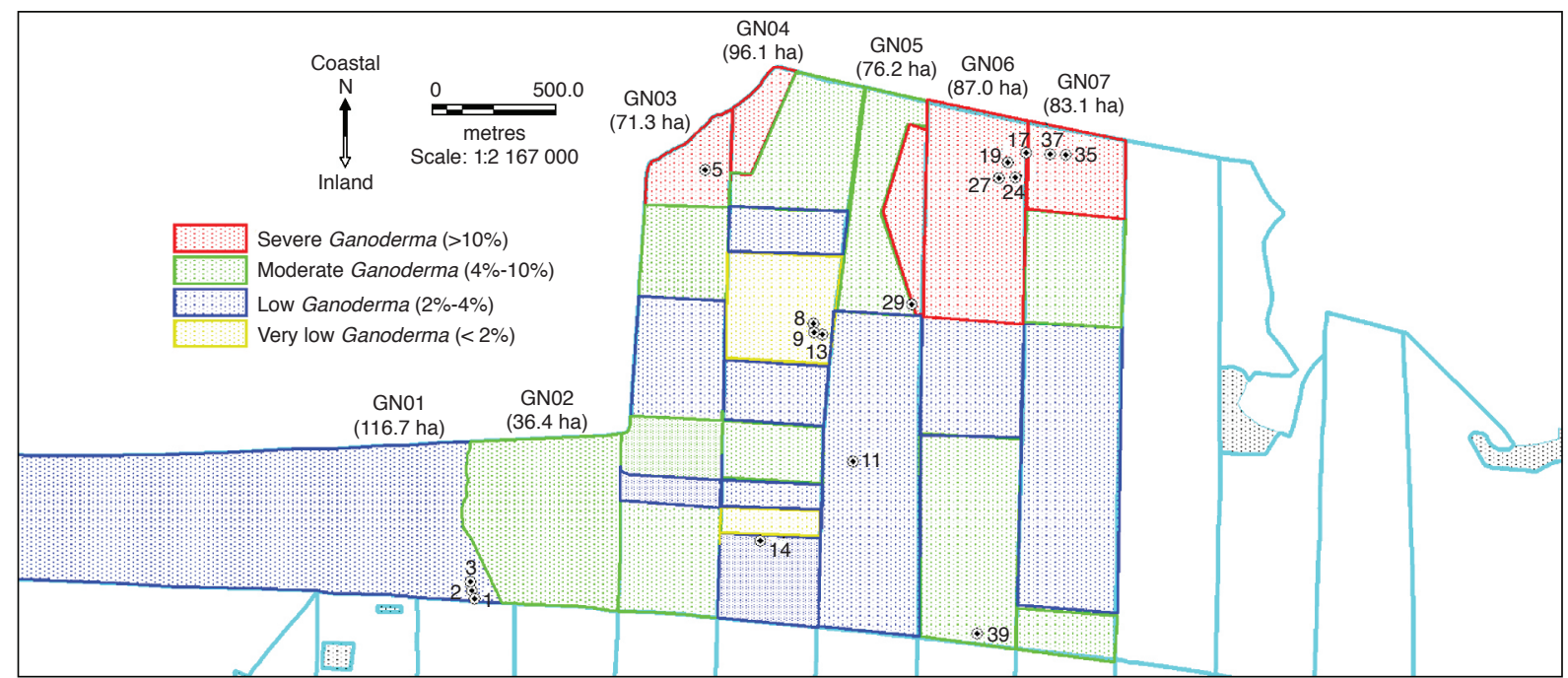

\begin{tabular}{|c|c|c|c|c|c|}
\hline Sampling point & $\begin{array}{c}\text { Ganoderma } \\
\text { isolate }\end{array}$ & Block & $\begin{array}{r}\text { Size } \\
\text { (ha) }\end{array}$ & $\begin{array}{c}\text { Total palms } \\
\text { (original) }\end{array}$ & $\begin{array}{l}\text { Total palms at the } \\
\text { time of sampling }\end{array}$ \\
\hline $\begin{array}{l}1 \\
2 \\
3\end{array}$ & $\begin{array}{l}\mathrm{B} / 1 / 001 \\
\mathrm{~B} / 1 / 002 \\
\mathrm{~B} / 1 / 003\end{array}$ & GN01 & 116.7 & 15873 & 14848 \\
\hline $\begin{array}{l}5 \\
8\end{array}$ & $\begin{array}{l}\mathrm{U} / 3 / 005 \\
\mathrm{~B} / 4 / 008\end{array}$ & GN03 & 71.3 & 9702 & 8296 \\
\hline $\begin{array}{r}9 \\
13 \\
14\end{array}$ & $\begin{array}{l}\mathrm{B} / 4 / 009 \\
\mathrm{~B} / 4 / 013 \\
\mathrm{~B} / 4 / 014\end{array}$ & GN04 & 96.1 & 13072 & 10608 \\
\hline $\begin{array}{l}11 \\
29\end{array}$ & $\begin{array}{l}\mathrm{B} / 5 / 011 \\
\mathrm{~B} / 5 / 029\end{array}$ & GN05 & 76.2 & 10366 & 8732 \\
\hline 17 & B / 6/017 & & & & \\
\hline 19 & B/6/019 & & & & \\
\hline 24 & B / 6/024 & GN06 & 87.0 & 11827 & 8340 \\
\hline $\begin{array}{l}27 \\
39\end{array}$ & $\begin{array}{l}\mathrm{B} / 6 / 027 \\
\mathrm{~B} / 6 / 039\end{array}$ & & & & \\
\hline 35 & $\mathrm{~B} / 7 / 035$ & GN07 & 83.1 & 11299 & 9045 \\
\hline 37 & $\mathrm{~B} / 7 / 037$ & & & & \\
\hline
\end{tabular}

Figure 1. Location map and background information of each sampling point at Gunung Nayo (GN), Block 1 to Block 7. 
TABLE 2. THE FUNGAL AND BACTERIAL SPECIES USED IN THE cDNA-SSR SCREENING TEST TO REMOVE THE cDNA-SSR MARKER THAT IS NOT SPECIFIC TO G. boninense

\begin{tabular}{|c|c|c|c|c|}
\hline No. & Sample ID & Identity & GenBank No. & Reference \\
\hline 2 & DG3 & Ganoderma boninense (USR) & MF682419 & This study \\
\hline 4 & E5 & Ganoderma boninense (BSR) & MF682421 & This study \\
\hline 5 & GL0 & Ganoderma lucidum & MF682422 & This study \\
\hline 8 & KB10 & Sphingomonas sp. & MF682428 & This study \\
\hline 9 & OTU6 & Aspergillus nomius & MF682423 & This study \\
\hline 10 & RB5 & Colletotrichum lupini & MF682424 & This study \\
\hline 11 & TCF13 & Penicillium charlesii & MF682425 & This study \\
\hline 12 & T3, Paloh G14 & Ganoderma boninense (BSR) & JQ665238 & Kok et al. (2013) \\
\hline 16 & T8, Pinji G1 & Ganoderma boninense (BSR) & JQ665226 & Kok et al. (2013) \\
\hline 17 & T9, Pelam G11 & Ganoderma boninense (BSR) & JQ665236 & Kok et al. (2013) \\
\hline 18 & T10, Batu Lintang G10 & Ganoderma boninense (BSR) & JQ665235 & Kok et al. (2013) \\
\hline 19 & T11, Bebar G4 & Ganoderma boninense (BSR) & JQ665229 & Kok et al. (2013) \\
\hline 20 & T12, Sungai Jernih G3 & Ganoderma boninense (BSR) & JQ665228 & Kok et al. (2013) \\
\hline 21 & T13, Sungai Sokor G9 & Ganoderma boninense (BSR) & JQ665234 & Kok et al. (2013) \\
\hline 22 & T14, Pasir Gajah G2 & Ganoderma boninense (BSR) & JQ665227 & Kok et al. (2013) \\
\hline
\end{tabular}

until the desired size of basidiocarp was reached (more than $50 \mathrm{~mm}$ ). However, unexpected toppling of some BSR infected palms limited the number of basidiocarps that could be collected. Eventually, only 36 basidiocarps were collected, from which 19 Ganoderma pure cultures were obtained. Two of the 19 Ganoderma mycelium cultures that were confirmed to be non-G. boninense by alignment of the $16 \mathrm{~S}$ and $18 \mathrm{~S}$ nucleotide sequences against the nonredundant nucleotide database at GenBank (NCBI) using default setting of Nucleotide BLAST (Basic Local Alignment Search Tool, https://blast.ncbi. nlm.nih.gov), were excluded from the phylogeny analysis and genotyping. Method of confirmation of Ganoderma identity confirmation is detailed in another section below.

\section{Ganoderma DNA Extraction}

Two sets of G. boninense isolates from Gunung Nayo, Belitung Island (Table 1) and BSR-affected plantations in Peninsular Malaysia (Table 2) were used in this study. The genomic DNA of G. boninense stored at the Indonesian Biotechnology Research Institute for Estate Crops (IBRIEC) was extracted according to the protocol described by Minarsih et al. (2011). The pure cultures of the isolates collected from Peninsular Malaysia were incubated for five days prior to genomicDNAextraction using FastDNAspin kit (MP Biomedicals, USA) for fungal isolates and GF-1 Bacterial DNA isolation kit (Vivantis, USA) for bacteria isolates as described by the manufacturers. Due to the different laboratory practices, two DNA extraction protocols were tested and optimised for obtaining good quality DNA and high yield for genotyping. All purified G. boninense genomic DNA samples were sent to AAR Biotechnology Laboratory, AAR-UNMC Biotechnology Research Centre, Semenyih, Selangor, Malaysia, for genetic diversity determination using the selected highly polymorphic cDNA-SSR markers.

\section{Identification of Non-Ganoderma Fungi and Bacterial Species}

The identity of isolates after subjected to marker screening toremovenon-G.boninense-specific cDNASSR markers, was confirmed using $16 S$ and 18SSUrRNA PCR-sequencing approach. The sequences obtained were examined by comparing them to the non-redundant nucleotide database at GenBank (NCBI). The $16 \mathrm{~S}$ rRNA forward and reverse primer sequences used for bacterial species identification were 27F 5'-AGAGTTTGATCMTGGCTCAG-3' and 1525R 5'-AAGGAGGTGWTCCARCC-3', respectively (Lane, 1991). For the identification of non-Ganoderma fungi, the forward primer SSU817-5' 5'-TTAGCATGGAATAATRRAATAGGA-3' and reverse primer SSU-1536-3' 5'ATTGCAATGCYCTATCCCCA-3 were used to amplify 18SSU-rRNA region (Borneman and Hartin, 2000) by using modified polymerase chain reaction (PCR) protocol described herein. The PCR reaction mixture $(50 \mu \mathrm{l})$ contained 0.1 Unit of Taq DNA Polymerase (iNtRON Biotechnology, Korea), 0.4 $\mu \mathrm{M}$ of each forward and reverse primers, $0.2 \mathrm{mM}$ 
dNTPs (iNtRON Biotechnology, Korea), 1X PCR buffer (supplied with $2 \mathrm{mM} \mathrm{MgCl}{ }_{2}$ ), $0.2 \mathrm{mg} \mu \mathrm{l}^{-1}$ bovine serum albumin (Amresco, USA), 5 to $10 \mathrm{ng}$ of template DNA and nuclease free water. The PCR programme used was one cycle of $94^{\circ} \mathrm{C}$ for $4 \mathrm{~min}$, $94^{\circ} \mathrm{C}$ for $20 \mathrm{~s}, 56^{\circ} \mathrm{C}$ for $10 \mathrm{~s}, 72^{\circ} \mathrm{C}$ for $60 \mathrm{~s}$, followed by 34 cycles of $94^{\circ} \mathrm{C}$ for $20 \mathrm{~s}, 56^{\circ} \mathrm{C}$ for $10 \mathrm{~s}$, and $72^{\circ} \mathrm{C}$ for $60 \mathrm{~s}$. Finally, the reaction was terminated with an additional extension of $5 \mathrm{~min}$ at $72^{\circ} \mathrm{C}$ before cooling to $10^{\circ} \mathrm{C}$. The thermocycling was performed with Veriti $^{\mathrm{TM}}$ Thermal Cycler (Applied Biosystem, USA). PCR products were visualised in $1.0 \% \mathrm{w} / \mathrm{v}$ agarose gel (Vivantis, USA) in 1X TBE buffer with $0.5 \times$ SYBR ${ }^{\circledR}$ Safe DNA gel stain (Invitrogen, USA) under $302 \mathrm{~nm}$ UV translumination using AlphaImager ${ }^{\circledR} \mathrm{HP}$ (Alpha Innotech, USA). Purified PCR products (MEGAquick-spin, iNtRON Biotechnology, Korea) were sent to Macrogen, Korea for sequencing analysis.

\section{Confirmation of Identity of Ganoderma Isolates}

The 17 ITS sequences from the genomic DNA of Gunung Nayo Ganoderma were amplified and sequenced for phylogenetic analysis. The primer pairs ITS1F': 5' CTT GGT CAT TTA GAG GAA GTA 3' and ITS4B': 5' CAGGAG ACT TGT ACA CGC TCC AG 3' (Grades and Bruns, 1993) were used to amplify the ITS region. The PCR reactions were performed using HotStarTaq Plus master mix (Qiagen, USA) with one cycle of $95^{\circ} \mathrm{C}$ for $15 \mathrm{~min}$, $94^{\circ} \mathrm{C}$ for $60 \mathrm{~s}, 58^{\circ} \mathrm{C}$ for $60 \mathrm{~s}, 72^{\circ} \mathrm{C}$ for $60 \mathrm{~s}$, followed by 34 cycles of $94^{\circ} \mathrm{C}$ for $60 \mathrm{~s}, 58^{\circ} \mathrm{C}$ for $60 \mathrm{~s}$, and $72^{\circ} \mathrm{C}$ for $60 \mathrm{~s}$. Finally, the reaction was allowed to terminate with an additional extension of $10 \mathrm{~min}$ at $72^{\circ} \mathrm{C}$ before cooling to $10^{\circ} \mathrm{C}$. The thermocycling was performed with Veriti ${ }^{\mathrm{TM}}$ Thermal Cycler (Applied Biosystem, USA). The PCR products were purified using Nucleospin Gel and PCR Clean-Up kit (Macherey Nagel, GmbH \& Co. KG) prior to cloning and sequencing at AIT Biotech, Singapore. The newly generated ITS sequences were submitted to GenBank (http://www.ncbi.nlm.nih.gov, Table 1). The phylogenetic analysis that was performed using Geneious R9 and MEGA 5.2 included the ITS sequences in this study and those from Genbank (Zhou et al., 2015). All ITS sequences were trimmed, and aligned with Clustal $\mathrm{W}$ using default setting. The phylogenetic trees were reconstructed using maximum likelihood (ML), Neighbour Joining (NJ) and unweighted pair group method with arithmetic mean (UPGMA).

\section{Ganoderma boninense Transcriptome Sequencing and Mining of Putative cDNA-SSR}

The two isolates from AAR and FGV R\&D were used in transcriptome sequencing. The Norgen's Plant/Fungi Total RNA Purification Kit
(Norgen, Biotek Corporation, Canada) was used to isolate high quality total ribonucleic acid (RNA) from $G$. boninense cultured in oil palm extract liquid medium (Kok et al., 2013). The integrity and quantity of total RNA were measured using NanoDrop 2000 (Thermo Fisher Scientific Inc., USA) and Qubit 2.0 RNA Broad Range Assay (Invitrogen, USA). The RNA integrity number (RIN) was determined using Agilent Bioanalyser RNA Nano chip. The two G. boninense RNA samples originally from AAR and FGV R\&D, with RIN more than 7.0, were recommended for transcriptome sequencing. Messenger RNA isolation and cDNA synthesis were performed using TruSeq RNA Sample Preparation Kit (Illumina, USA) and SuperScript II Reverse Transcriptase (Invitrogen, USA) according to manufacturer's protocol. The synthesised cDNA was quantitated using Qubit 2.0 DNA Broad Range Assay (Invitrogen, USA). A minimum of 15 ng cDNA was fragmented using Covaris S220 (Covaris Inc, USA) to a targeted size of 200-300 bp. The fragmented cDNA were then end-repaired, ligated to Illumina TruSeq adapters, and PCRenriched using TruSeq RNA Sample Preparation Kit (Illumina, USA) according to manufacturer's protocol. The final sequencing libraries were quantified using KAPA kit (KAPA Biosystem, USA) on Agilent Stratagene Mx-3005p quantitative PCR (Agilent, USA) and sizes were confirmed using Agilent BioAnalyzer High Sensitivity DNA Chip (Agilent, USA). The resulting sequencing libraries were sequenced using an Illumina flow cell and 209 cycles on the Illumina HiSeq 2000 platform (Illumina, USA). G. boninense sequences were pre-processed by removing the low quality bases (average reads with quality score less than 20) before being de novo assembled using Trinity (Grabherr et al., 2013). The Trinity contigs were re-assembled by using PHRAP (http:/ / www.phrap.org/phredphrap/phrap.html) to remove redundancies and contigs with higher reliability (i.e. more than $300 \mathrm{bp}$ ) were harvested. Using the MIcroSAtellite identification tool (MISA, http: / / pgrc.ipk-gatersleben.de/ misa/misa.html) programme, the pool of di-, tri-, tetra-, pentaand hexa-nucleotide repeats of $G$. boninense were predicted. Only microsatellite sequences (minimum of six repeats) with flanking sequence longer than $50 \mathrm{bp}$ on both sides were chosen for primer design using BatchPrimer3 (http://probes.pw.usda.gov/ batchprimer3/). The parameters of the primer design were (1) primer length of 18-20 bases, (2) melting temperature ranging from $40^{\circ} \mathrm{C}-60^{\circ} \mathrm{C}$, (3) $40 \%-60 \%$ of GC content and (4) product size of 100 to $400 \mathrm{bp}$.

\section{cDNA-SSR Polymorphism Analysis}

The initial screening for polymorphic cDNASSR markers was carried out utilising a 6\% polyacrylamide gel electrophoresis and banding 
profiles were detected using the silver staining protocol described by Gustavo and Peter (1994). The Peninsular Malaysia collection of G. boninense isolates that were obtained from BSR and USR diseased oil palm, Ganoderma lucidum, Bacillus shackletonii, Paenibacillus sp., Sphingomonas sp., Aspergillus nomius, Colletotrichum lupine and Penicillium charlesii (Table 2) were used for cDNASSR polymorphism testing. The PCR mixture consisted of $20 \mu \mathrm{l}$ of DyNAzyme II PCR Master

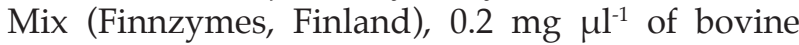
serum albumin (Amresco, USA), approximately $40 \mathrm{ng}$ of DNA template and $1 \mu \mathrm{M}$ of both forward and reverse SSR primers. The thermocycling programme was the same as described for $16 \mathrm{~S}$ and $18 \mathrm{~S}$ rRNA analysis. The CERVUS software, version 3.0.3 (Marsha!l et al., 1998) was used to analyse and calculate the informativeness of SSR markers, i.e. number of alleles (K) generated from genotyped isolates, observed heterozygosity $\left(\mathrm{H}_{\mathrm{o}}\right)$, expected heterozygosity $\left(\mathrm{H}_{\mathrm{e}}\right)$ and polymorphism information content (PIC).

\section{Genotyping of Gunung Nayo Isolates}

The selected polymorphic cDNA-SSR markers were converted into IRDye ${ }^{\circledR}$-detection markers, in which a fusion of the forward CDNA-SSR primer with an M13 (-29) tail, 5'-CACGACGTTGTAAAACGAC-3' (19 bp) at the $5^{\prime}$ end was synthesised for PCR amplification (Schuelke, 2000). During the PCR amplification, the universal IRDye ${ }^{\circledR}$-labelled M13 (-29) primer was incorporated into the PCR reaction for labelling the PCR products with the fusion primer and standard reverse primer. Higher resolution of genetic profile for $G$. boninense was achieved when DINA genotyping was performed on NEN 4300 DNA Analyser (Li-COR Biosciences, USA). PCR mixture consisting of $5 \mu$ l of TopTaq Master Mix Kit (Qiagen, Germany), approximately $40 \mathrm{ng}$ of DNA template, $0.05 \mu \mathrm{M}$ of M13 Forward (-29) IRDye $^{\circledR} 700$ primer, $0.5 \mu \mathrm{M}$ of each primer and 1.5 $\mu \mathrm{l}$ of nuclease free water to make up a volume of $10 \mu \mathrm{l}$ reaction. The PCR programme used was one cycle of $94^{\circ} \mathrm{C}$ for $3 \mathrm{~min}, 94^{\circ} \mathrm{C}$ for $30 \mathrm{~s}, 55^{\circ} \mathrm{C}$ for 30 $\mathrm{s}, 72^{\circ} \mathrm{C}$ for $60 \mathrm{~s}$, followed by 34 cycles of $94^{\circ} \mathrm{C}$ for $30 \mathrm{~s}, 55^{\circ} \mathrm{C}$ for $30 \mathrm{~s}, 72^{\circ} \mathrm{C}$ for $60 \mathrm{~s}$ and an additional extension of $10 \mathrm{~min}$ at $72^{\circ} \mathrm{C}$ before cooling to $10^{\circ} \mathrm{C}$. The thermocycling was performed with Veriti ${ }^{\mathrm{TM}}$ Thermal Cycler (Applied Biosystem, USA). Binary and codominant scoring was carried out manually to avoid misinterpretation of mixed intensity DNA fragment patterns. Hierarchical cluster analysis was carried out using the multivariate statistical package MVSP (Kovach Computing Services, Anglesey, Wales) to genetically distinguish the G. boninense isolates collected from areas with different levels of disease severity.

\section{Ganoderma boninense Genetic Diversity Analysis}

The mycelium of a single spore culture of G. boninense only has one allele at each locus, whereas pure mycelial culture isolated from basidiocarp (or rotted trunk tissue of BSR infected oil palm) showed either one or two alleles per locus. This confirmed that $G$. boninense has a dikaryon phase $(n+n)$ in the course of invading an oil palm. For the purpose of measuring G. boninense genetic diversity in Gunung Nayo, we assumed that each pure mycelial culture represented at least two alleles per locus. The allele frequencies, heterozygosity, Shannon's information index and Fixation index within the Gunung Nayo population were calculated according to frequency-based statistical procedures described in GenAlEx 6.5 (Peakall and Smouse, 2012). This information is useful for characterising the allelic diversity and genetic variation of the G. boninense isolates. Pairwise, isolate-by-isolate genetic distance matrix was generated from cDNA-SSR codominant marker data for subsequent Principal Coordinate Analysis (PCoA). In combination with the hierarchical clustering results, the distinct groups and spread patterns within the Gunung Nayo population were deduced and inferred by the selected high polymorphic cDNA-SSR markers.

\section{RESULTS}

\section{Sampling of Ganoderma boninense in Gunung Nayo}

At the initial stage of field sampling, we identified a total of $36 \mathrm{G}$. boninense infected palms comprising 34 BSR palms and two USR palms. As described by Rees et al. (2012), USR palm should have the basidiocarp positioned at trunk height more than $2 \mathrm{~m}$ above the ground level and without apparent BSR symptoms (Figure 2). However, we observed some of the basidiocarps could be found on the base of a few infected palms, extending to a trunk height exceeding $2 \mathrm{~m}$. Therefore, we classified USR as an infected palm showing decay of upper stem without basidiocarp emergence at its base. A total of 21 basidiocarps were successfully sampled from Gunung Nayo. Two out of the 21 isolates were determined by $18 S S U-r R N A$ as not Ganoderma boninense, and the DNA of another two isolates were difficult to re-dissolve in TE buffer and were not genotyped. This resulted in only 17 pure G. boninense cultures obtained from 21 out of 36 identified palms processed at the IBRIEC. To ascertain that G. boninense is predominantly responsible for the BSR infection in oil palms, basidiocarps were only sampled from standing infected oil palm. In Gunung Nayo, basidiocarp emergence tended to be 

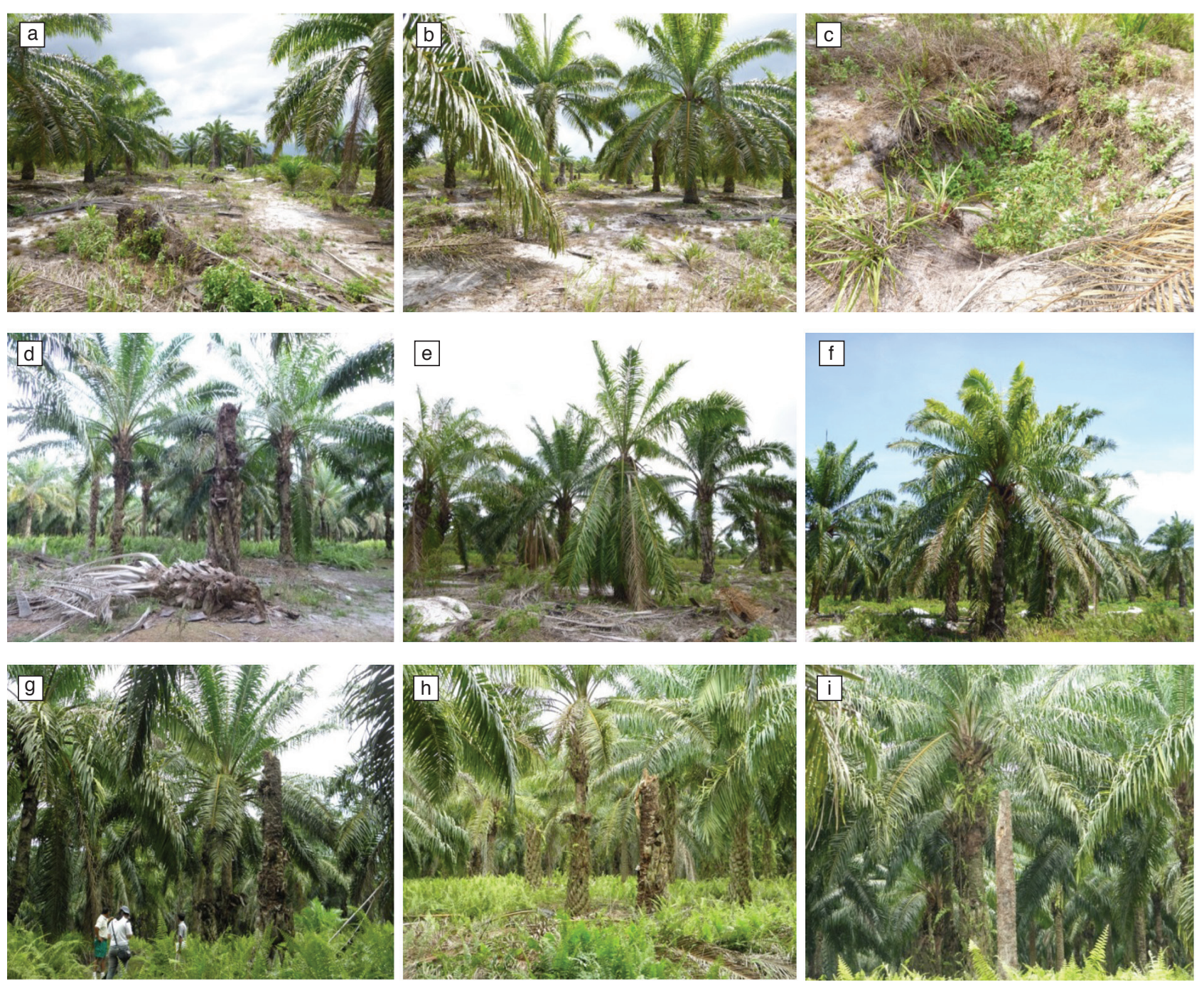

Figure 2. Comparison of different basal stem rot (BSR) disease severity from the coastal area towards inland at Gunung Nayo. a-c: Severe infection area, $>10 \%$ planted oil palm were visibly BSR infected oil palm (coastal area); $d-f:$ moderate infection area, 4\%-10\%; g-i: low infection area, $2 \%-4 \%$ (inland area).

higher after a period of heavy rainfall (November to December) compared to the drier season (August to September). Therefore, the most suitable sampling period was February to April, after the high rainfall season in Gunung Nayo. The weather effect on basidiocarp emergence outlined above suggests that multiple samplings in the same planting blocks at different time points, i.e. temporal sampling and assessment, could be a more precise approach to generate unbiased genetic relatedness information for studying the pattern of disease spread.

\section{Identify of Gunung Nayo Isolates}

In this study, the identity of 17 isolates from Gunung Nayo were examined with molecular phylogenetic approaches. The amplification of internal transcribed spacer (ITS) region in the nuclear ribosomal repeat unit, to be specific to basidiomycetes, yielded approximately $765 \mathrm{bp}$.
After the trimming of ambiguous sequence sites at the $3^{\prime}$ and $5^{\prime}$-ends, the sequences of the 17 isolates were aligned with the published ITS dataset of Ganoderma species (Zhou et al., 2015) and newly generated ITS sequence of $G$. boninense PER71 (Taxonomy ID: 1262459 and GenBank accession No.: PRJNA182005) using the protocol described in this article. The phylogenetic trees constructed using distance methods, i.e. NJ and UPGMA and character-based method, i.e. ML shared similar topology in which all the Gunung Nayo isolates consistently grouped under the same Clade with G. boninense (designated as G. boninense_PER71, WD2025, and WD2028).

The phylogeny results confirmed that the 17 Gunung Nayo isolates were G. boninense. The topology derived from ML is presented in Figure 3. The topology derived from NJ and UPGMA analysis, as well as the matrix data are provided as supplementary material S1 and S2. 


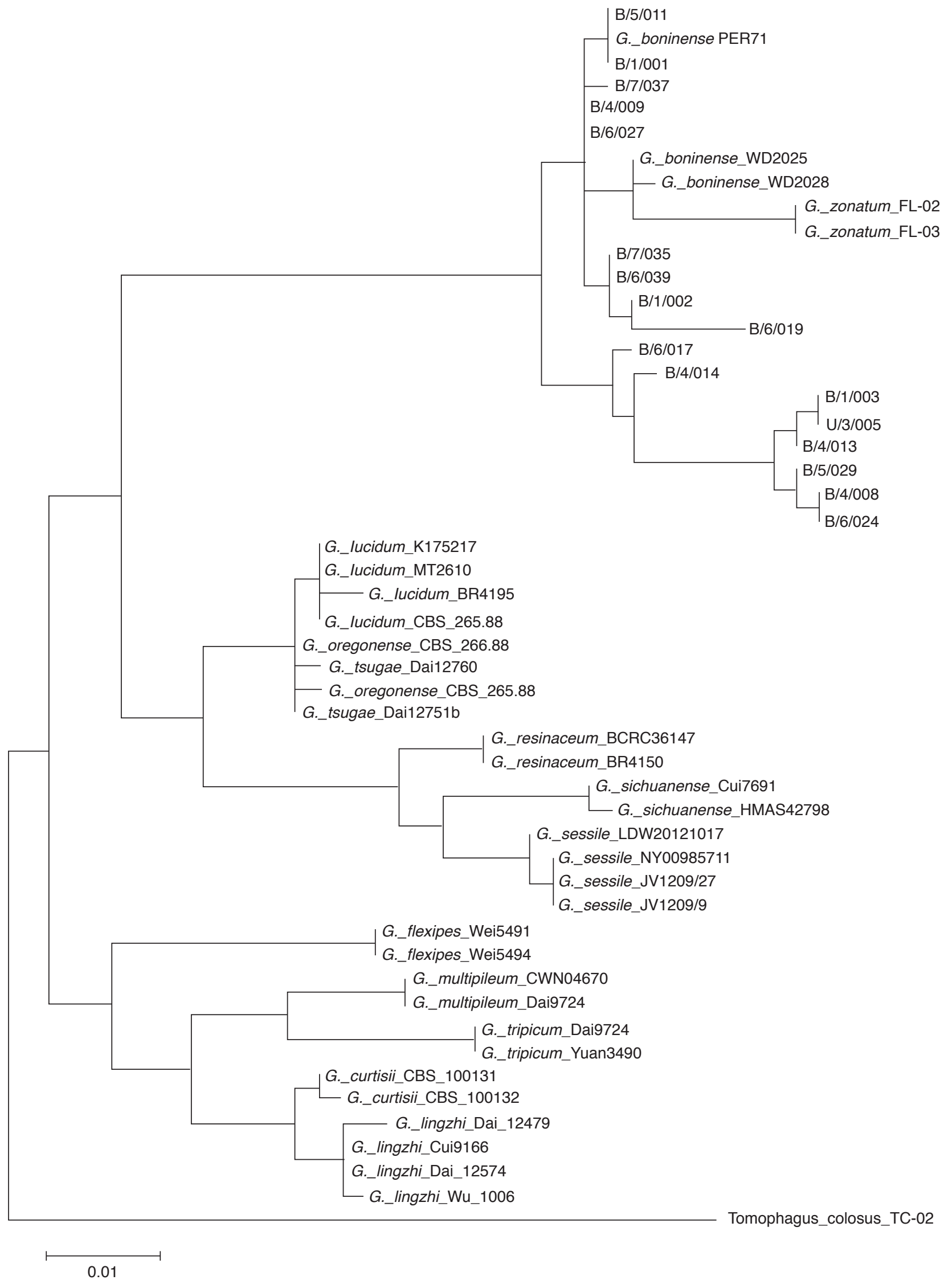

Figure 3. Phylogeny of the Ganoderma species based on the internal transcribed spacer (ITS) sequences comparison between the Gunung Nayo isolates with the published list of Ganoderma species (Zhou et al., 2015) and G. boninense PER71 that originated from Malaysia (Taxonomy ID: 1262459). The topology is derived from the maximum likelihood analysis. 


\section{Mining of Putative cDNA-SSR from Ganoderma boninense Transcriptomes}

Two de novo assembled Ganoderma boninense transcriptomes (unpublished data) were used for the discovery of microsatellites or cDNA-SSR markers in this study. Using the program MISA, the $\mathrm{di}^{-}$, tri-, tetra and penta-nucleotide repeats of the G. boninense transcripts were identified. Only microsatellite sequences found in both transcriptomes, with a minimum of six repeats, and flanking sequences longer than $50 \mathrm{bp}$ were chosen for CDNA-SSR marker development.

The results showed that a total of 879 microsatellites were identified from 857 G. boninense transcripts that accounted for 481 di-, 377 tri-, 17 tetra- and 4 penta-nucleotide repeats. Microsatellites that were successfully used for designing the PCR primers with adequate amplification were screened for their polymorphism and specificity to G. boninense using the samples listed in Table 2.

\section{Selection of Polymorphic cDNA-SSR Markers}

A total of 24 polymorphic cDNA-SSR markers were pre-determined by their polymorphism using G. boninense, G. lucidum, B. shackletonii, Paenibacillus sp., Sphingomonas sp., A. nomius, C. lupine and P. charlesii, all originating from Peninsular Malaysia. The cDNA-SSR markers with PIC more than 0.35 (Table 3) and without band amplification observed from other bacterial and fungal samples were chosen for genotyping the $G$. boninense isolates sampled from Gunung Nayo. Allelic diversity by locus was estimated using heterozygosity $\left(\mathrm{H}_{\mathrm{o}}\right.$ and $\left.\mathrm{H}_{\mathrm{e}}\right)$ and PIC value.

Further to this study, cDNA-SSR markers with PIC and discriminating power $\left(\mathrm{D}_{j}\right)$ of more than 0.5 were used as a standard criterion to identify the informative and high polymorphic marker for distinguishing the $G$. boninense isolates by genotypic clustering approach. The $\mathrm{D}_{j}$ for each of the loci can be calculated according to Tessier et al. (1999).

Results showed that 10 out of the 24 screened cDNA-SSR markers were each successful in genotyping all isolates from Gunung Nayo with $\mathrm{H}_{\mathrm{e}^{\prime}}$ PIC and $\mathrm{D}_{j}$ values exceeding 0.5 . These $10 \mathrm{cDNA}$ SSR markers were GBP4_1, GBP4_10, GBP4_24, GBP4_28, GBP4_40, GBP4_62, GBP4_64, GBP5_11, GBP5_13, GBP6_11 (Table 4). The mean expected heterozygosity for the population of 17 isolates was 0.777 and the combined non-exclusion probability (identity) for this set of 10 SSR markers was $1.979^{\mathrm{E}-11}$.

\section{Marker-inferred Spread Pattern of G. boninense}

Following a measure of UPGMA cluster analysis, the 17 Gunung Nayo G. boninense isolates can be resolved into five groups, designated A to E, at the EUCLID distance of 6.00 (Figure 4 and Supplementary Material S3). The isolates collected from severe, moderate, low and very low disease incidence areas were distinctly separated using the 10 selected cDNA-SSR marker without noticeable genetically similar or clonal G. boninense isolates in this study.

Isolates $\mathrm{B} / 7 / 037$ and $\mathrm{B} / 6 / 024$ that formed Group A in cluster analysis were sampled closest to coastal areas between blocks GN07 and GN06 and had high BSR disease incidence whereas isolates B/5/011 and B / 4 / 014 (Group B) were collected from areas with low BSR disease incidence, i.e. in blocks GN05 and GN04. Their genetic profiles suggested that the corresponding isolates within and between the Groups A and B have closer genetic relatedness, compared to Group C (single isolate B/7/035) and the major groups of isolates, i.e. Groups $\mathrm{D}$ and $\mathrm{E}$.

Group D consisted of isolates B / 6/027, B / 6/ 019, B/5/ 029, B / 4/ 013, B / 4/ 009, B / 4 / 008 and U/3/005 that could be further classified into two subgroups. The isolates in the first subgroup were collected from high disease incidence area (i.e. $\mathrm{B} / 6 / 027$, $\mathrm{B} / 6 / 019, \mathrm{~B} / 5 / 029$ and $\mathrm{U} / 3 / 005$ ) in the coastal, northern part of Gunung Nayo and the second subgroup in very low BSR disease incidence areas towards the inland south (i.e. B/4/013, B/4/009 and B/4/008 in block GN04). The distinctive genetic clustering of isolates in Group D hints at the initial inoculum originating from the severe areas (coastal) moving towards the very low disease incidence areas (inland) as shown by the genetic linkage of $G$. boninense isolates from the inland areas to $\mathrm{B} / 5 / 029$ and $\mathrm{B} / 6 / 019$ or B / 6/ 027 in the coastal areas (Figure $5)$. This suggested that the initial sources, $B / 6 / 019$ and or B/6/027, had spread from the coastal areas to inland areas over a significant distance (i.e. approximately $1 \mathrm{~km}$ ) between blocks GN06 and GN04. The observed different disease incidences at blocks GN06 (severe), GN05 (moderate) and GN04 (very low) may be a reflection of different infection times, i.e. disease started in severely infected fields first and subsequently spread to medium, low and very low disease incidence fields.

Similarly, clustering results showed that Group E comprised the majority of isolates from inland areas, i.e. blocks GN01 (i.e. B/1/001, $\mathrm{B} / 1 / 002$ and $\mathrm{B} / 1 / 003)$ and GN06 (B/6/039). The only exception was isolate B /6/017 sampled from the north, closer to coastal area where BSR incidence was high. In Group F, the clustering of the isolates can possibly be used to deduce the disease spread from the north towards the south when more isolates are subjected to the same genotyping analysis.

The current results from using the 10 selected cDNA-SSR markers profiles to examine the population structure of Gunung Nayo G. boninense isolates showed that the population may consist 


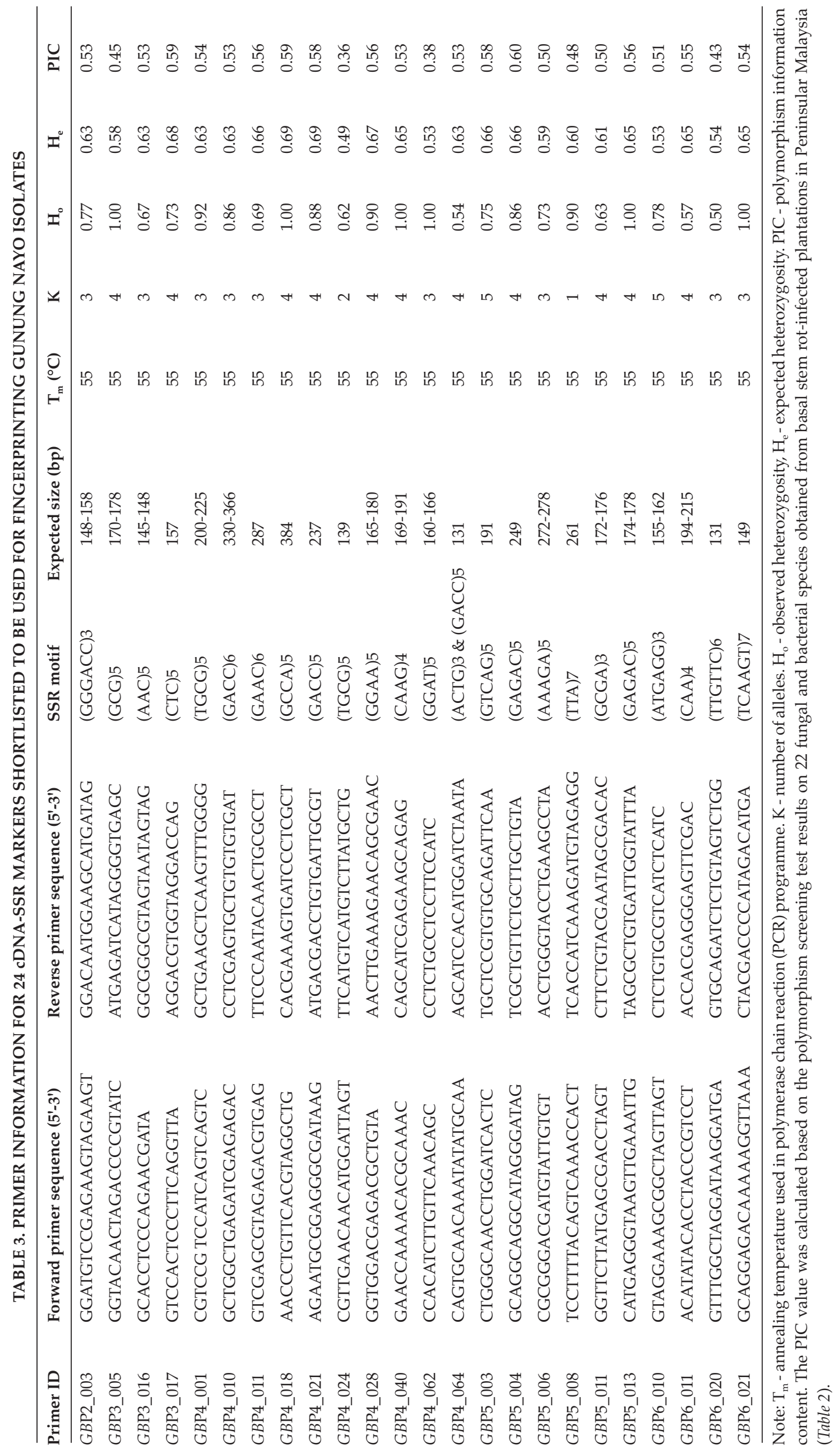


TABLE 4. THE HETEROZYGOSITY, POLYMORPHIC INFORMATION CONTENT (PIC) AND DISCRIMINATING POWER OF THE 10 cDNA-SSR MARKERS USED FOR Ganoderma GENETIC DIVERSITY STUDY AT GUNUNG NAYO

\begin{tabular}{llcccccc}
\hline No. & Locus & $\mathbf{K}$ & $\mathbf{N}$ & $\mathbf{H}_{\mathbf{o}}$ & $\mathbf{H}_{\mathrm{e}}$ & $\mathbf{P I C}_{j}$ \\
\hline 1 & GBP4_1 & 8 & 16 & 0.500 & 0.881 & 0.836 \\
2 & GBP4_10 & 10 & 17 & 0.471 & 0.847 & 0.803 \\
3 & GBP4_24 & 6 & 17 & 0.529 & 0.665 & 0.584 & 0.910 \\
4 & GBP4_28 & 10 & 17 & 0.471 & 0.824 & 0.781 \\
5 & GBP4_40 & 3 & 16 & 0.500 & 0.635 & 0.536 \\
6 & GBP4_62 & 4 & 17 & 0.529 & 0.654 & 0.584 \\
7 & GBP4_64 & 10 & 17 & 0.412 & 0.845 & 0.801 \\
8 & GBP5_11 & 6 & 17 & 0.059 & 0.790 & 0.731 \\
9 & GBP5_13 & 7 & 17 & 0.471 & 0.840 & 0.675 \\
10 & GBP6_11 & 11 & 17 & 0.235 & 0.814 \\
\hline
\end{tabular}

Note: $\mathrm{K}$ - number of alleles at the SSR locus. $\mathrm{N}$ - number of individuals genotyped. $\mathrm{H}_{\mathrm{o}}$ - observed heterozygosity. $\mathrm{H}_{\mathrm{e}}-$ expected heterozygosity.

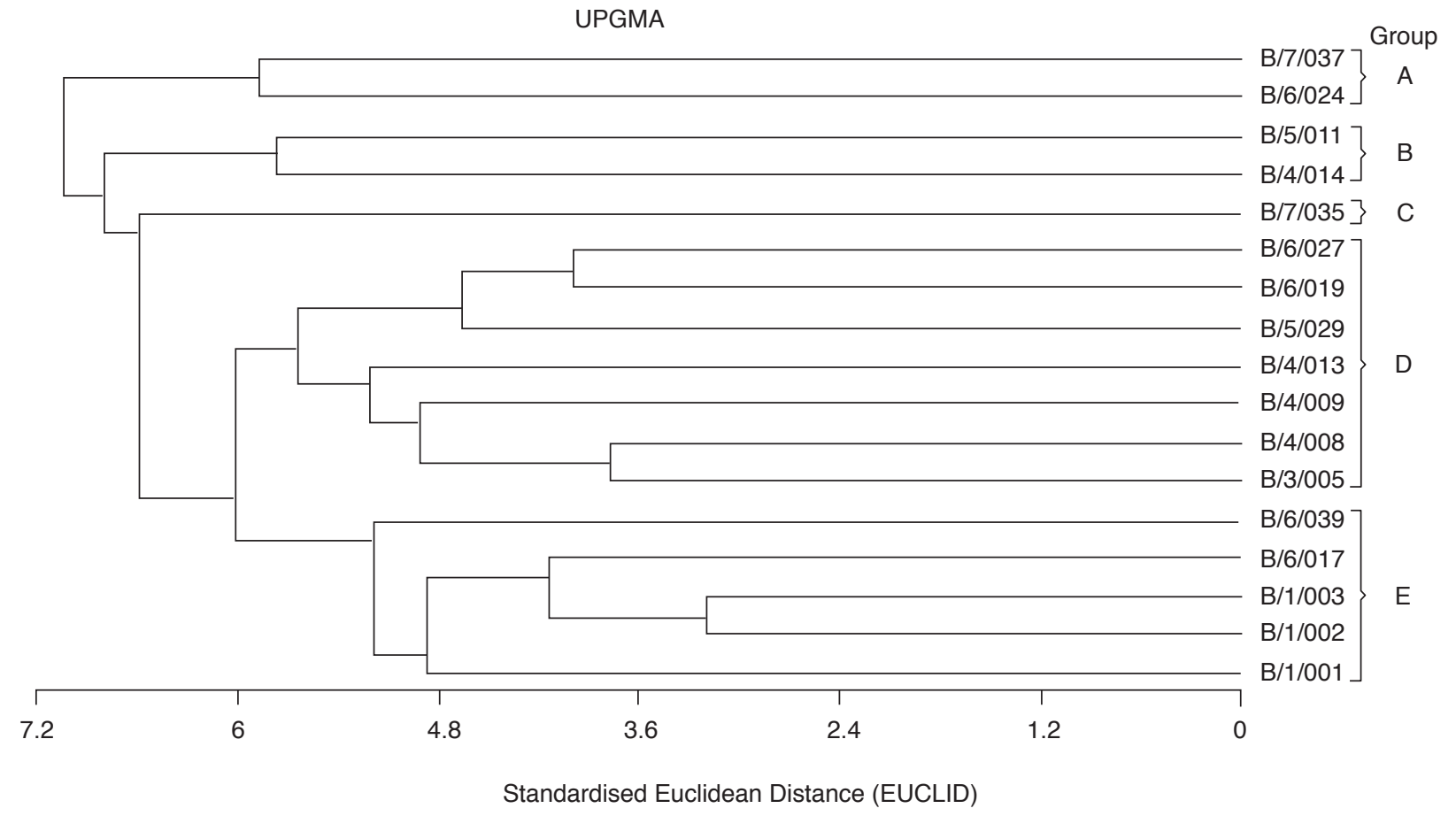

Figure 4. The unweighted pair group method with arithmetic mean (UPGMA)-based dendogram generated from genotyping of 17 Gunung Nayo isolates using 10 polymorphic cDNA-SSR markers, i.e. GBP4_01, GBP4_10, GBP4_24, GBP4_28, GBP4_40, GBP4_62, GBP4_64, GBP5_11, GBP5_13 and GBP6_11. Genotypic clustering of isolates corresponds to different blocks and disease severity (Table 1).

of several distinct subpopulations without clonal lineages. This needs further confirmation using larger sample size from the same sampling sites.

\section{Estimation of Genetic Diversity of Gunung Nayo Isolates}

A total of 47 alleles of $G$. boninense were successfully fingerprinted with the 10 cDNA-SSR markers (Table 4) in spite of the $11 \%$ missing data at the loci 'GBP4_64', 'GBP5_11' and 'GBP6_11'. These 47 alleles were used to compute the Shannon's Information Index (SI), unbiased heterozygosity $\left(\mathrm{uH}_{\mathrm{e}}\right)$ and Fixation Index (FI) over the $17 \mathrm{G}$. boninense isolates in Gunung
TABLE 5. THE DIVERSITY MEASURE OF THE 17 G. boninense ISOLATES FROM GUNUNG NAYO

\begin{tabular}{ccc}
\hline \multirow{2}{*}{$\begin{array}{c}\text { Diversity } \\
\text { measure }\end{array}$} & \multicolumn{2}{c}{ Grand total } \\
\cline { 2 - 3 } & Mean & Standard error \\
\hline $\mathrm{N}_{\mathrm{a}}$ & 4.700 & 0.396 \\
$\mathrm{~N}_{\mathrm{e}}$ & 3.542 & 0.340 \\
$\mathrm{SI}$ & 1.345 & 0.089 \\
$\mathrm{H}_{\mathrm{o}}$ & 0.325 & 0.077 \\
$\mathrm{uH}_{\mathrm{e}}$ & 0.719 & 0.026 \\
$\mathrm{FI}$ & 0.527 & 0.116 \\
\hline
\end{tabular}

Note: $\mathrm{N}_{\mathrm{a}}$ - mean number of alleles. $\mathrm{N}_{\mathrm{e}}$ - number of effective alleles. SI - Shannon's information index. $\mathrm{H}_{\mathrm{o}}$ - observed heterozygosity. $\mathrm{uH}_{\mathrm{e}}$ - unbiased heterozygosity.

FI - fixation index. 


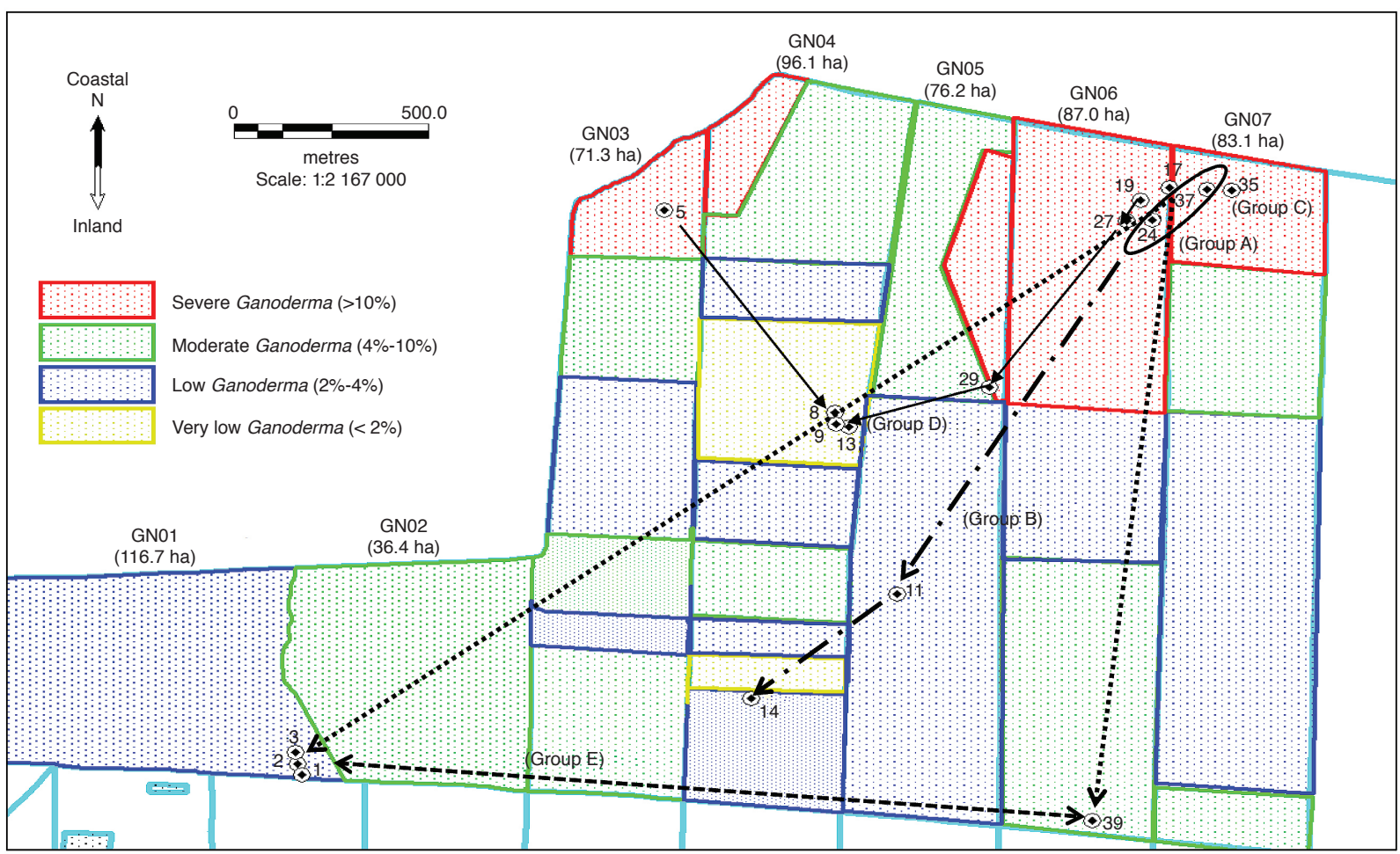

Figure 5. Basal stem rot (BSR) disease spread patterns deduced from the G. boninense genetic clusters. Grouping of isolates A to E corresponds to the clustering results depicted in Figure 4. Numbers 1-39 are referring to the sampling site of the BSR and upper stem rot diseased oil palm.

Nayo (Table 5). An average of $3.542( \pm 0.340)$ effective alleles were generated for meaningful comparison of the allelic diversity across 10 loci with diverse allele frequency distribution. Diverse genetic variability of $G$. boninense was explained by high SI, $1.345 \pm 0.089$, and $\mathrm{uH}_{\mathrm{e}^{\prime}} 0.719 \pm 0.026$. The calculated high value of FI, $0.527 \pm 0.116$, implied undetected null alleles within the population of Gunung Nayo. Multiple population analysis would be required for F-statistics (Nagylaki, 1998) analyses to determine the differentiation of genetic structure of Gunung Nayo isolates.

In an attempt to characterise the spread pattern of Gunung Nayo G. boninense isolates, we used pairwise genetic distance matrix as input and the relationship between the 17 Gunung Nayo isolates were performed with the distance-standardised principal coordinates analysis (PCoA) method. The PCoA resulted in five major groups of $G$. boninense separated by Coordinates 1 and 2 (Figure 6). Percentage variation explained by the three Coordinates were calculated as Coordinate 1, 20.61\%; Coordinate $2,18.10 \%$ and Coordinate $3,16.49 \%$. The proximity genetic relatedness among the majority of G. boninense isolates found in Gunung Nayo was not influenced by the isolate's origin, i.e. BSR or USR $(\mathrm{U} / 3 / 005)$ diseased oil palm. Notably, the grouping of isolates was nearly identical to the hierarchical clustering results (Figure 4). PCoA results provided further supporting evidence for the population that $G$. boninense isolates spread from coastal to inland areas. Isolate $\mathrm{B} / 4 / 013$ was distinguished from isolate $\mathrm{B} / 4 / 008$ and $\mathrm{B} / 4 / 009$ by Coordinate 1 Distance despite being clustered together under Group D. Besides, the isolate B / 4 / 013 was grouped closely to isolate $\mathrm{B} / 6 / 024$ which suggests that outcrossing of $\mathrm{B} / 4 / 013$ might have occurred over several generations prior to its spreads to Block GN04. Similarly, PCoA showed that isolates B/5/029 collected from block GN05 had closer genetic relatedness to $B / 4 / 008$ and $B / 4 / 009$ from the very low BSR disease incidence area. However, it was also genetically associated with isolates B/6/019 and B/6/027 from block GN06 with high BSR disease severity (coastal area) as confirmed by both clustering and PCoA results.

Overall, the group of genetically related isolates B/6/019, B/6/027, B/5/29, B/4/008 as shown by their Coordinate 1 Distance suggested possible course of G. boninense spreads from blocks GN06 to GN04 as discussed below.

\section{DISCUSSION}

\section{Molecular Markers for G. boninense}

Molecular markers for epidemiological study of $G$. boninense are scarce. In the past, the type of molecular markers that were utilised for studying the genetic structure of this fungal pathogen are limited to the use of vegetative incompatibility 


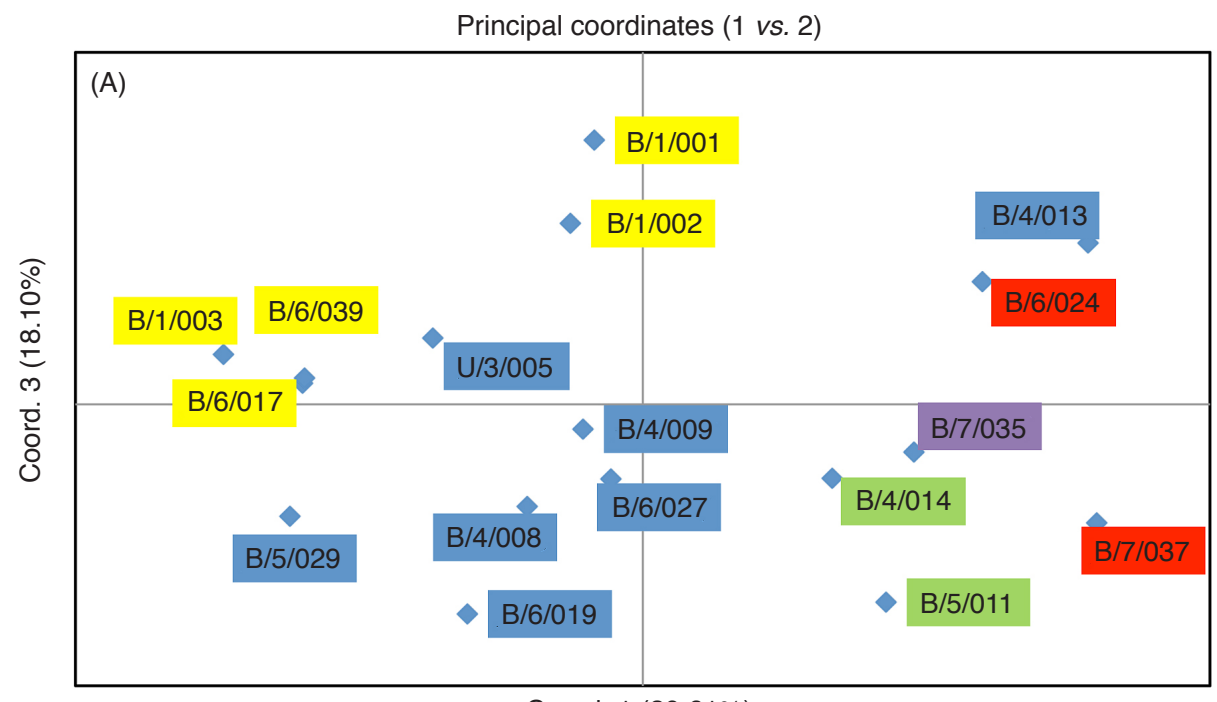

Coord. $1(20.61 \%)$

Principal coordinates (1 vs. 3)

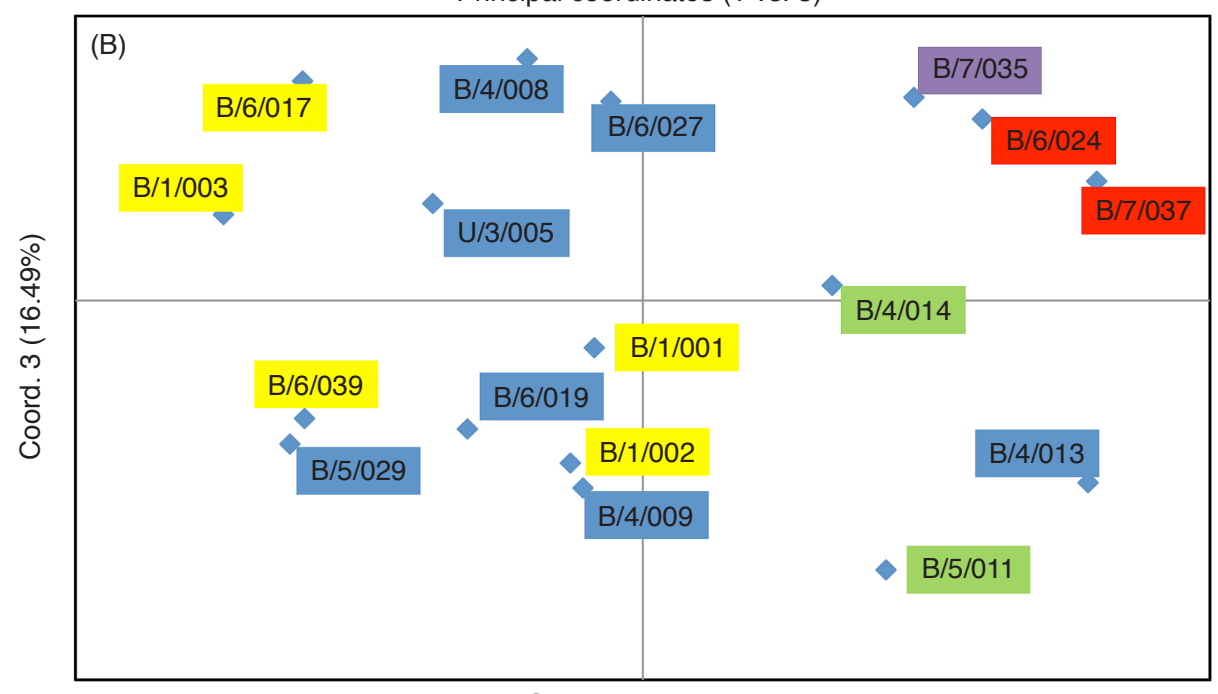

Coord. $1(20.61 \%)$

Principal coordinates (2 vs. 3)

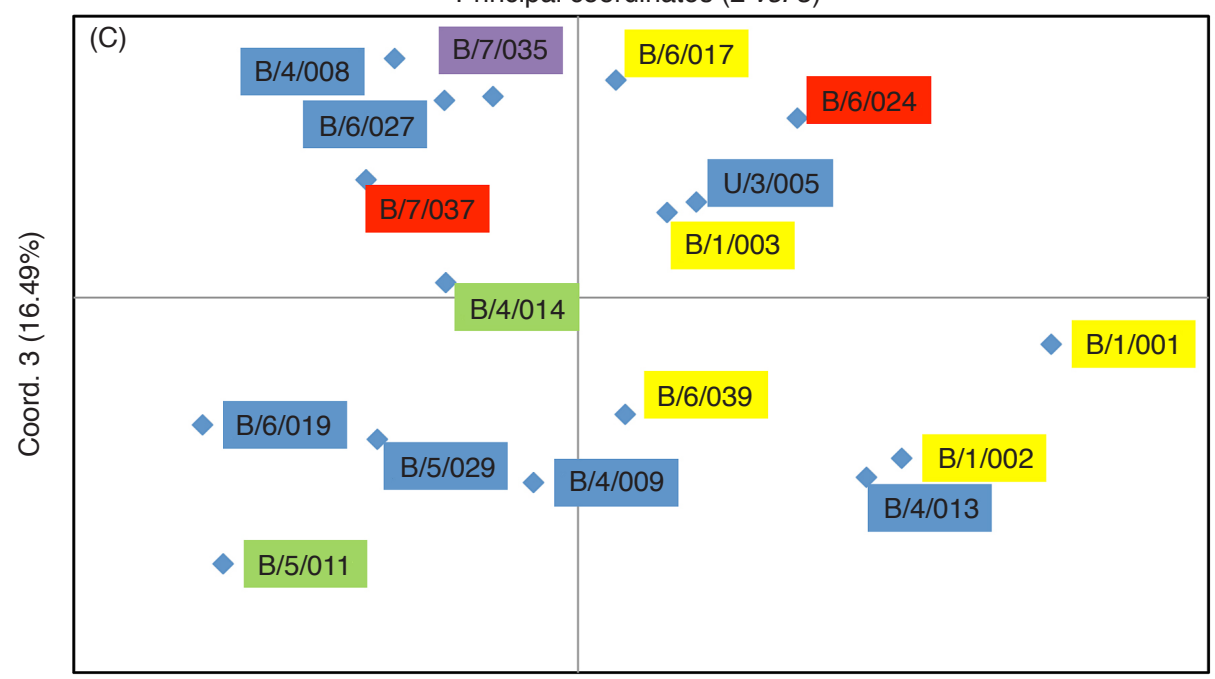

Coord. $2(18.10 \%)$

Figure 6. The Principal Coordinate Analysis (PCOA) plots presented the relationship of the $17 \mathrm{G}$. boninense isolates collected from a single population, Gunung Nayo. The genetic variation was explained by the first three principal coordinates (axes). Plot of A: Coordinate 1 vs. 2, B: Coordinate 1 vs. 3 and C: Coordinate 2 vs. 3. Coloured label corresponds to the hierachical clustering results, i.e. Red: Group A; Green: Group B; Purple: Group C; Blue: Group D and Yellow: Group E. 
groups (VCG) analysis and restriction fragment length polymorphism (RFLP) to detect mtDNA variability (Miller et al., 1999; Pilotti et al., 2000; 2003; Pilotti, 2005), random amplified polymorphic DNA (RAPD) and randomly amplified microsatellites (RAM) (Zakaria et al., 2005; Rees et al., 2012) mainly carried out in Papua New Guinea, Malaysia and Indonesia. VCG study was a cultural technique used for studying the population genetics of $G$. boninense before the advent of molecular marker methods. The application of VCG for genotyping is limited because of the difficulty in identifying heterozygotes when one allele is functionally dominant for the targeted phenotype (Milgroom, 2015). Similarly, concerns were raised with the use of RFLP, the first codominant marker was used for studying fungi population and evolution (Förster et al., 1987), because the alleles cannot be assigned unambiguously to specific loci and therefore, they will be scored as dominant marker in RFLP fingerprinting. RAPD and RAM are arbitrary PCRbased markers and are not locus-specific, resulting in the lack of G. boninense specificity and could possibly amplify DNA from contaminants introduced during field sampling, culturing and preparation of DNA samples.

Mercière et al. (2015) was the first to report the identification of microsatellite markers using genome assembly for G. boninense. They developed a substantial number of genomic-derived microsatellite markers where from 2487 SSR, 145 SSR primer pairs were designed and a set of 17 screened SSR were identified to study G. boninense diversity. Genome-assisted derived SSR having the nature of marker neutrality, codominance, high polymorphism and reproducibility made the microsatellite fingerprinting the method of choice for studying the population genetics and evolution of G. boninense (Mercière et al., 2017).

Our attempt to use the transcriptome of G. boninense for developing microsatellite markers (termed as EST-SSR or CDNA-SSR) was driven by the successful application of cDNA-SSR for population study of grape powdery mildew fungus, Erysiphe necator (Frenkel et al., 2012). Before G. boninense genome becomes publicly available (GenBank accession No. LFMK01000000), mining the putative cDNA-SSR from the depth and coverage of de novo transcriptome of G. boninense, which was a non-model fungal pathogen has been the most targeted, efficient and cost-effective method. In this study, the common cDNA-SSR identified from two versions of transcriptomes produced from two $G$. boninense isolates provided the greatest confidence of specificity to $G$. boninense gene-coding regions of DNA. As reported by Breuillin et al. (2006) in the genetic diversity studies of four populations of chestnut blight fungus Cryphonectria parasitica in France, there was no systematic difference in the allelic diversity of cDNA-SSR loci in coding regions compared to those genomic SSR which were assumed to be neutral.

Secondly, the specificity, polymorphism and reproducibility of the current set of 24 cDNASSR markers were tested in which non-Ganoderma boninense markers had been removed by filtering using a representative set of $G$. boninense isolates and other fungal and bacterial species isolated from BSR diseased areas (Tables 2 and 3). The basidiocarps of $G$. boninense often have microbes associated with them and may also harbour insect pests. Under these circumstances, it is important to sample fresh basidiocarps and use GSM to isolate the G. boninense pure cultures for DNA extraction prior to genotyping. Direct DNA extraction from the cortex tissue of basidiocarps resulted in high background noise being detected on the ITS sequences (unpublished data) and therefore the identity of the fungal isolate cannot be ascertained. The genetic variability of $G$. boninense populations might be confounded by this biological noise if the specificity of the marker is not fully optimised and identity of the isolate is not confirmed (Bridge et al., 2005). It is vital to examine the identity of the isolates to the current accepted species level using ITS sequences and molecular phylogeny analyses as detailed in the previous section (Figure 3). The successful use of molecular marker for $G$. boninense genetic diversity studies is highly dependent on the fungal group and its associated microorganisms within or between the oil palm estates. Our study has demonstrated the advantage of utilising the $16 \mathrm{~S}$ and $18 \mathrm{~S}$ analyses to investigate the absence or presence of other fungus and bacterial species in the DNA template and ITS sequences were used to examine the identity of Gunung Nayo isolates.

As for polymorphism testing, a total of 879 cDNASSR identified from the de novo transcriptomes were manually curated to ascertain that the markers were not overlapping on the specific transcript sequences or located on different chromosomes since genetic linkage analysis was not performed in our study. The shortlisted cDNA-SSR (Table 3) indicated there was no bias for the selection of cDNA-SSR motif and number of repeats for genotyping of $G$. boninense isolates in Gunung Nayo. Early research had also suggested that the number of alleles found at the fungus SSR is weakly correlated to the number of repeats (Dutech et al., 2007), but a minimum of five repeats may give rise to higher polymorphism as evidenced in our screening result (Table 3) (Frenkel et al., 2012). Further to the investigation of allelic diversity by locus across $17 \mathrm{G}$. boninense isolates in a single population (from one location), the selected 10 cDNA-SSR markers (Table 4) showed that the estimated heterozygosity $\left(\mathrm{H}_{\mathrm{o}}\right.$ and $\left.\mathrm{H}_{\mathrm{e}}\right)$ and PK value were relatively higher than previously published data (Mercière et al., 2015). Mercière et al. reported the genetic diversity deduced by 17 
SSR fingerprinting of 107 basidioscarps obtained from Peninsular Malaysia (40 samples, $\mathrm{H}_{\mathrm{o}}=0.100$ to 0.800 and $\mathrm{H}_{\mathrm{e}}=0.229$ to 0.847 ), Borneo (20 samples, $\mathrm{H}_{\mathrm{o}}=0.059$ to 0.842 and $\mathrm{H}_{\mathrm{e}}=0.304$ to 0.840$)$ and North Sumatra (47 samples, $\mathrm{H}_{\mathrm{o}}=0.106$ to 0.830 and $\mathrm{H}_{\mathrm{e}}=$ 0.406 to 0.830 ). Their overall calculated PIC ranged from 0.298 to 0.813 in contrast to the present study using $10 \mathrm{G}$. boninense specific cDNA-SSR markers genotyping of 17 Gunung Nayo isolates yielded PIC value of 0.536 to $0.836\left(\mathrm{H}_{\mathrm{o}}=0.059\right.$ to 0.529 and $\mathrm{H}_{\mathrm{e}}$ $=0.635$ to 0.881 ). However, this comparison is still weak and a larger scale genotyping of isolates and populations using the CDNA-SSR markers will be needed to evaluate the reliability and accuracy of the marker-inferred genetic diversity of G. boninense found in South-east Asia. Nevertheless, the cDNASSR developed for population genetics of G. boninense were as good as the previous molecular markers used and are not limited by the aforementioned marker characteristics used in other studies. The appraisal of practical application of the cDNASSR marker for inferring the genetic structures and processes (gene flow, migration, mutation, genetic drift, etc.) of emergence and re-emergence of $G$. boninense during replanting of oil palm (second and third generations) at different regions in Malaysia are currently on-going.

\section{Genetic Diversity, Clustering of Isolates and Disease Spread}

Our epidemiological studies of G. boninense using cDNA-SSR markers began by sampling from populations at Gunung Nayo. Despite no early detection method of $G$. boninense, the basidiocarp emergence at the advanced stage of BSR disease occurs sporadically in nature, making representative population difficult to sample. Cross-country genetic diversity study of $G$. boninense presented additional logistical challenges for sampling of basidiocarps, dikaryon pure culture isolation, transferability of DNA extraction protocols and recovery of DNA. The genotyping results generated from the dikaryotic mycelial cultures might not fully dissect the genetic divergence of the Gunung Nayo population. Operationally, the remoteness of the sampling site (a first generation oil palm planting with high BSR-infected oil palms) and low germination rate of spores (Ho and Nawawi, 1986) made it difficult to obtain monokaryons and cross them to produce dikaryons for genotyping.

In our study, the selected 10 out of the 24 polymorphic cDNA-SSR markers with relatively high PIC values ranging from 0.536 to 0.836 (Table 4) were sufficient to determine the genetic diversity of G. boninense in Gunung Nayo. The allelic diversity measures (Table 5) which showed high heterozygosity, imply that outcrossing, which results in diversification, is common within the population of $G$. boninense isolates. This is in agreement with the findings of Pilotti et al. (2002; 2003), although they did not report the heterozygosity of G. boninense. Random samples that truly represent the population and using more than 20 marker loci would be ideal to obtain a reasonable estimate of the amount of genetic diversity in a population (Ritland, 2000). Larger samples size, for example 100 or more samples, is better to address questions related to population expansion, gene flow and dispersion of G. boninense as reported by Mercière et al. (2017). However, in most studies of population genetics of plant pathogens, 8 to 15 polymorphic microsatellitte markers were sufficient for estimating the genetic diversity (Nakabonge et al., 2008; Hadziabdic et al., 2014) and spread pattern of the pathogens (Schoebel et al., 2014).

Hierarchical clustering using EUCLID distance measures indicated a high degree of genetic similarity among the Gunung Nayo isolates which corresponds well to their geographical proximities and offered plausible spread pattern from coastal areas to the inland areas. Isolates from the north end of blocks GN06 and GN07, which had a high level of disease incidence, were representatives in four genotypic clusters, i.e. Groups A, C, D and E, making it the likely source of dispersion to the rest of the areas shown in the map (Figures 4 and 5). In PCoA, the correlated genetic variations combined into individual vectors that were used to plot the position and genetic distances between the isolates in multidimensional scale to further dissect the genetic variability of Gunung Nayo isolates (Figure 6). The segregation of the 17 isolates by Coordinates 1 $(20.61 \%)$ and $2(18.10 \%)$ was generally in agreement with the result of hierarchical clustering based on EUCLID distance. PCOA confirmed that the 17 isolates from Group A to E were distinct and the cDNA-SSR marker-inferred groupings were relatively well separated. Isolate B/4/013, one of these isolates from the very low disease area of GN04, was consistently not grouped together with the isolates from Group D. Chronological record of G. boninense emergence, long distance spore dispersal from coastal to inland areas and pathogenicity of the G. boninense are still largely unknown for the Gunung Nayo population. Another factor that hampered the current assessment of the pathogen population structure and the pathogen spread pattern was the number of generations of crossing amongst the G. boninense isolates. The cDNA-SSR marker inferred genetic variation contributed from natural recombinant spores, hence, it might not truly represent the pathogen genetic diversity and relatedness at the time of BSR disease establishment. Thus, it might provide less accurate information on the pathogen's population structure and disease spread pattern. Measures to improve the genotyping 
and estimation of genetic diversity include the random sampling of basidiocarps and spores over time, reproducible DNA genotyping with the inclusion of positive and negative controls, testing of fungal pathogenicity, and comparative correlation between the monokaryon and dikaryons in the natural population of Ganoderma isolates.

\section{CONCLUSION}

In this study, we describe the development of a set of cDNA-SSR markers and practically applied them to determine the genetic variation of G. boninense in a pre-defined population. This was a pilot study to evaluate the sampling constraints, method for screening of cDNA-SSR marker (easy to score, reproducible and inexpensive) and determine the markers suitable for genetic diversity and relatedness analyses. While the selected 10 polymorphic cDNA-SSR markers, with their discriminating power $\left(\mathrm{D}_{j}\right)$ more than 0.65 (Table 4) were proven to be effective in distinguishing between $G$. boninense isolates from both coastal and inland areas where BSR disease severity was different, but no evidence shows that cDNA-SSR functions with the pathogenicity of $G$. boninense. In the first generation of oil palm planting at Gunung Nayo, the G. boninense isolates collected from standing infected palms were genetically different from palm to palm. There was no clonal BSR infection in the present study. Our research suggests that genetic variation of $G$. boninense probably plays a vital role in enabling the fungal pathogen to adapt to its new habitat (planting blocks) and host (oil palm), as well as its ability to overcome new forms of resistance or tolerance in oil palm crosses. Therefore, it is of importance to have molecular markers and statistical methods to quantify the changes in allele frequency and gene flow that determine the pathogen's evolutionary potential and the genetic structure of G. boninense before effective disease control methods can be developed for BSR in oil palm.

\section{SUPPLEMENTARY INFORMATION}

The supplementary materials containing (S1) the additional phylogeny results analysed using NJ and UPGMA methods; (S2) the matrix output of the estimation of evolutionary divergence between ITS sequences using ML method; and (S3) the distance matrix of $17 \mathrm{G}$. boninense isolates deduced from fingerprinting profile by 10 selected high polymorhic cDNA-SSR markers can be found via http://jopr. mpob.gov.my/wp-content/uploads/2019/04/jopr 2019-tung-supplimentary.pdf

\section{ACKNOWLEDGEMENT}

We gratefully acknowledge our principals, Boustead Plantations Berhad and Kuala Lumpur Kepong Berhad, for the financial support given to the research activities that generated the data presented here and their permission to publish this article. We thank John Edward (General Manager of PT. SWP Belitung, Indonesia), Manveeran Suppiah (Senior Manager of Gunung Nayo Estate) and Faried Afthoni (Manager of Gunung Nayo Estate), for permission and assistance to carry out the G. boninense genetic diversity study in Gunung Nayo, Belitung Island. We are grateful to Felda Global Ventures Research \& Development Sdn Bhd for contributing one Ganoderma boninense basidiocarp from Serting Hilir Research Station, Negeri Sembilan, for pathogen transcriptome sequencing. We would also like to thank Patrick Chia Jing Yi (Bioinformatics-Transcriptome Team, Malaysian Genomics Resource Centre Berhad, Malaysia) for assisting in bioinformatics analyses of $G$. boninense transcriptomes and mining of CDNA-SSR sequences. We are especially grateful to Dr Denita Hadziabdic (Department of Entomology and Plant Pathology, University of Tennessee, USA) and the late Dr Richard Cooper (Department of Biology and Biochemistry, University of Bath, United Kingdom) for their insights and critical reviews of the draft manuscript.

\section{REFERENCES}

Ariffin, D and Idris, A S, (1991). A selective medium for isolation of Ganoderma from diseased tissues. Proc. of the 1991 International Palm Oil Conference, Progress, Prospects and Challenges towards the 21 Century. MPOB, Bangi. p. 517-519.

Ariffin, D and Idris, A S (2002). Progress and research on Ganoderma basal stem rot of oil palm. Proc. of the Seminar on Recent Progress in the Management of Peat and Ganoderma. MPOB, Bangi. p. 50.

Brewer, M T and Milgroom, M G (2010). Phylogeography and population structure of the grape powdery mildew fungus, Erysiphe necator, from diverse Vitis species. BMC Evol. Biol., 10: 268280.

Bridge, P D; Spooner, B M and Roberts, P J (2005). The impact of molecular data in fungal systematics. Adv. Bot. Res., 42: 33-67.

Borneman, J and Hartin, R J (2000). PCR primers that amplify fungal rRNA genes from environmental samples. Appl. Environ. Microbiol., 66(10): 43564360 . 
Breuillin, F; Dutech, C and Robin, C (2006). Genetic diversity of the chestnut blight fungus Cryphonectria parasitica in four French populations assessed by microsatellite markers. Mycol. Res., 110: 288-296.

Cannon, P F and Sutton, B C (2011). Microfungi on wood and plant debris. Biodiversity of Fungi: Inventory and Monitoring Methods (Mueller, G M; Bills, G F and Foster, M S eds.). Academic Press, USA. p. 217-240.

Chung, G F (2011). Management of Ganoderma disease in oil palm plantation. The Planter, 87(1022): 325-339.

Cooper, R M; Flood, J and Rees, R W (2011). Ganoderma boninense in oil palm plantations: Current thinking on epidemiology, resistance and pathology. The Planter, 87(1024): 515-526.

Dutech, C; Enjalbert, J; Fournier, E; Delmotte, F; Barres, B; Carlier, J; Tharreau, D and Giraud, T (2007). Challenges of microsatellite isolation in fungi. Fungal Genet. Biol., 44: 933-949.

Flood, J; Hasan, Y and Foster, H (2002). Ganoderma disease of oil palm - An interpretation from Bah Lias Research Station. The Planter, 78(921): 689-710.

Förster, H; Kinscherf, T G; Leong, S A and Maxwell, D $P$ (1987). Restriction fragment length polymorphism of the mitochondrial DNA of Phytophthora megasperma isolated from soybean, alfalfa and fruit trees. Can. J. Bot., 67: 529-537.

Frenkel, O; Portillo, I; Brewer, M T; Péros, J P; Cadle-Davidson, L and Milgroom, M G (2012). Development of microsatellite markers from the transcriptome of Erysiphe necator for analysing population structure in North America and Europe. Plant Pathol., 61: 106-119.

Grabherr, M G; Haas, B J; Yassour, M; Levin, J Z; Thompson, D A; Amit, I; Adiconis, X; Fan, L; Raychowdhury, R; Zeng, Q; Chen, Z; Mauceli, E; Hacohen, N; Gnirke, A; Rhind, N; Palma, F; Birren, B W; Nusbaum, C; Lindblad-Toh, K; Friedman, N and Regev, A (2013). Trinity: Reconstructing a fulllength transcriptome without a genome from RNASeq data. Nat. Biotechnol., 29(7): 644-652.

Grades, M and Bruns, T D (1993). ITS primers with enhanced specificity for basidiomycetes-application to the identification of mycorrhizae and rusts. Mol. Ecol., 2: 113-118.

Gustavo, CA and Peter, M G (1994). Staining nucleic acids with silver: An alternative to radioisotopic and fluorescent labelling. Promega Notes Magazine. Promega, Madision, WI, USA. p. 13-20.

Hadziabdic, D; Vio, L M; Windham, M T; Pscheidt, J W; Trigiano, R N and Kolarik, M (2014). Genetic differentiation and spatial structure of Geosmithia morbida, the causal agent of thousand cankers disease in black walnut (Juglans nigra). Curr. Genet., 60: 75-87.

Ho, YW and Nawawi, A (1986). Germination studies of Ganoderma boninense spores from oil palms in Malaysia. Pertanika, 9(2): 151-154.

Idris, A S and Ariffin, D (2004). Basal stem rot Biology, detection and control. Proc. of the International Conference on Pests and Diseases of Importance to the Oil Palm Industry. MPOB, Bangi. p. 134-165.

Khairudin, H (1990). Results of four trials on Ganoderma basal stem rot of oil palm in Golden Hope estates. Proc. of the Ganoderma Workshop (Ariffin, D and Jalani, B S eds.). PORIM, Bangi. p. 67-80.

Kok, S M; Goh, Y K; Tung, H J; Goh, K J; Wong, W C and Goh, Y K (2013). In vitro growth of Ganoderma boninense isolates on novel palm extract medium and virulence on oil palm (Elaeis guineensis) seedlings. Malays. J. Microbiol. 9(1): 33-42.

Lane, D J (1991). 16S / $23 S$ rRNA sequencing. Nucleic Acid Techniques in Bacterial Systematics (Stackebrandt, E and Goodfellow, M eds.). Wiley, New York,USA. p. $115-175$.

Lim, K H and Udin, W (2010). Management of Ganoderma in peat soil in Indonesia. Proc. of the Second International Seminar on Oil Palm Diseases: Advances in Ganoderma Research and Management. Yogyakarta, Indonesia. p. 11.

Marshall, T C; Slate, J; Kruuk, L E B and Pemberton, J M (1998). Statistical confidence for likelihoodbased paternity inference in natural populations. Mol. Ecol., 7: 639-655.

Mercière, M; Boulord, R; Carasco-Lacombe, C; Klopp, C; Lee, Y P; Tan, J S; Sharifah Shahrul Rabiah, S A; Zaremski, A; De Franqueville, H; Breton, F and Camus-Kulandaivelu, L (2017). About Ganoderma boninense in oil palm plantations of Sumatra and Peninsular Malaysia: Ancient population expansion, extensive gene flow and large-scale dispersion ability. Fungal Biol., 121(67): 529-540.

Mercière, M; Laybats, A; Carasco-Lacombe, C; Tan, J S; Klopp, C; Durand-Gasselin, T; Sharifah Shahrul Rabiah, S A; Camus-Kulandaivelu, L and 
Breton, F (2015). Identification and development of new polymorphic microsatellite markers using genome assembly for Ganoderma boninense, causal agent of oil palm basal stem rot disease. Mycol. Progress., 14: 103. DOI:10.1007/s11557015-1123-2.

Milgroom, M G (2015). Population Biology of Plant Pathogens: Genetics, Ecology and Evolution. APS Press, USA. 399 pp.

Miller, R N G; Holderness, M; Bridge, P D; Chung, G F and Zakaria, M H (1999). Genetic diversity of Ganoderma in oil palm plantings. Plant Pathol., 48: 595-603.

Minarsih, H; Palupi, D L; Taniwiryono, D and Herliyana, E H (2011). Analisis keragaman genetik Ganoderma spp. yang berasosiasi dengan tanaman kakao dan tanaman pelindungnya menggunakan random amplified polymorphic DNA (RAPD). Menara Perkebunan, 79(1): 6-14.

Nagylaki, T (1998). Fixation indices in subdivided populations. Genetics, 148: 1325-1332.

Nakabonge, G; Burgess, T; Gryzenhout, M; Wingfield, B; Wingfield, M J and Roux, J (2008). Population structure of the fungal pathogen Holocryphia eucalypti in Australia and South Africa. Australas. Plant Path., 37: 154-161.

Navaratnam, S J (1964). Basal stem rot of oil palm on ex-coconut states. The Planter, 40: 256-259.

Oliva, J; Bendz-Hellgren, M and Stenlid, J (2011). Spread of Heterobasidion annosum s.s. and Heterobasidion parviporum in Picea abies 15 years after stump inoculation. FEMS Microbiol. Ecol., 75: 414429.

Peakall, R and Smouse, P E (2012). GenAlEx 6.5: Genetic analysis in Excel. Population genetic software for teaching and research - An update. Bioinformatics, 28: 2537-2539.

Pilotti, C A (2005). Stem rots of oil palm caused by Ganoderma boninense: Biology and epidemiology. Mycopathologia, 159: 129-137.

Pilotti, C A; Sanderson, F R and Aitken, E A B (2002). Sexuality and interactions of monokaryotic and dikaryotic mycelia of Ganoderma boninense. Mycol. Res., 106(11): 1315-1322.

Pilotti, C A; Sanderson, F R and Aitken, E A B (2003). Genetic structure of a population of Ganoderma boninense on oil palm. Plant Pathol., 52: 455-463.
Pilotti, C A; Sanderson, F R; Aitken, E A B and Bridge, P D (2000). Genetic variation in Ganoderma spp. From Papua New Guinea as revealed by molecular (PCR) methods. Ganoderma Diseases of Perennial Crops (Flood, J; Bridge, P D and Holderness, M eds.). CABI Publishing, Wallingford, UK. p. 195-204.

Rees, R W; Flood, J; Hasan, Y; Wills, M A and Cooper, R M (2012). Ganoderma boninense basidiospores in oil palm plantations: Evaluation of their possible role in stem rots of Elaeis guineensis. Plant Pathol., 61: 567578.

Ritland, K (2000). Marker-inferred relatedness as a tool for detecting heritability in nature. Mol. Ecol., 9: 1195-1204.

Schoebel, C N; Stewart, J; Gruenwald, N J; Rigling, D and Prospero, S (2014). Population history and pathways of spread of the plant pathogen Phytophthora plurivora. PLoS ONE. 9(1): e85368. DOI: 10.1371 / journal.pone.0085368.

Schuelke, M (2000). An economic method for the fluorescent labeling of PCR fragments: A poor man's approach to genotyping for research and highthroughput diagnostics. Nat. Biotechnol., 8: 233-234.

Singh, G (1991). Ganoderma - The scourge of oil palms in the coastal areas. The Planter, 67(786): 421-444.

Steyaert, R L (1967). Les Ganoderma pamicoles. Bull. Jard. Bot. Natl. Belg., 37: 485-492.

Tessier, C; David, J; This, P; Boursiquot, J M and Charrier, A (1999). Optimisation of the choice of molecular markers for varietal identification in Vitis vinifera L. Theor. Appl. Genet., 98: 171-177.

Thompson, A (1931). Stem rot of the oil palm in Malaya. Bull. Dep. Agric., Straits Settlements and F.M.S. Science Series, 6: 23.

Turner, P D (1981). Oil Palm Diseases and Disorders. Oxford University Press, Kuala Lumpur, Malaysia. $280 \mathrm{pp}$.

Zakaria, L; Kulaveraasingham, H; Tan, S G; Abdullah, F and Ho, Y W (2005). Random amplified polymorphic DNA (RAPD) and random amplified microsatellite (RAMS) of Ganoderma from infected oil palm and coconut stumps in Malaysia. Asia-Pac J. Mol. Biol., 13(1): 23-34.

Zhou, L W; Cao, Y; Wu, S H; Vlasák; Li, D W; Li, M J and Dai, Y C (2015). Global diversity of the Ganoderma lucidium complex (Ganodermataceae, Polyporales) inferred from morphology and multilocus phylogeny. Phytochemistry, 114: 7-15. 